\title{
Sera from Type 2 (non-insulin-dependent) diabetic and healthy subjects contain different amounts of a very low molecular weight growth peptide for vascular cells
}

\author{
T. Koschinsky, C. E. Bünting, R. Rütter and F.A. Gries \\ Diabetes Research Institute, Düsseldorf, FRG
}

\begin{abstract}
Summary. Diabetic angiopathy may be due, in part, to increased growth in vascular cells. We have investigated serum growth factors in Type 2 (non-insulin-dependent) diabetic and healthy subjects and their effect on cultured human arterial smooth muscle cells and fibroblasts. Removal of the dialyzable serum fraction (mol. wt. $<12,000$ ) reduced the growth effect of the diabetic sera by $37 \%(2 p<0.005)$ and of the nondiabetic sera by only $8 \%(2 p<0.01)$. In contrast, there was no difference in growth stimulation between the dialyzed diabetic or non-diabetic sera. Complete recovery of the dialyzable serum growth fraction was also obtained at a mol. wt. below 3,500 . Ten times the concentration of the low molecular weight growth factor (mol. wt. $<3,500$ ) from diabetic sera stimulated growth of fibroblasts or arterial smooth muscle cells by a mean of $243 \%$ or $174 \%$ and from non-diabetic sera by a mean of $146 \%$ or $137 \%$, respectively $(2 p<0.01)$. The growth stimulating potency of this serum fraction (mol. wt.
\end{abstract}

$<3,500$ ) contained in $10 \%$ diabetic sera, was two to ten times higher than that of human growth hormone or insulin, added in amounts equivalent to $10 \%$ or physiological serum concentrations. This diabetic serum growth factor was further characterized by: (1) linear dependence of growth stimulation over a concentration range of twenty times and by (2) reduction of the growth stimulating activity to control levels by pretreatment: (a) at $95^{\circ} \mathrm{C}$ for $30 \mathrm{~min}$, or (b) with two different proteases: Serva pronase E (Streptomyceus griseus) or Calbiochem protease (Subtilisin calsberg). Increased amounts of the very low molecular weight serum growth peptide in Type 2 diabetes might easily penetrate the arterial wall, thus contributing to the genesis of angiopathy.

Key words: Type 2 diabetes, very low molecular weight serum growth peptide, human arterial smooth muscle cells, fibroblasts, cell culture, diabetic angiopathy.
Increased vascular cell growth contributes, in part, to diabetic angiopathy. This increased growth may be under the influence of growth factors, present in sera of both diabetic and non-diabetic subjects. In Type 2 diabetic subjects, dialyzable serum growth factors (mol. wt. $<12,000$ ) stimulate increased growth and protein synthesis in human arterial smooth muscle cells and fibroblasts [1]. The increased growth-stimulating effect of these diabetic serum factors depends on metabolic control as it tends to occur in poorly controlled but not in well controlled Type 2 diabetes [2].

As the nature of these growth factors (mol. wt. $<12,000$ ) is unknown, we have studied their effect on human mesenchymal cells in vitro in relation to (1) their specificity for diabetes, (2) their relative potency compared with growth hormone, insulin, glucagon and cortisol, and (3) their physicochemical properties, including temperature and $\mathrm{pH}$ stability, molecular weight and peptide nature.

\section{Subjects and methods}

\section{Subjects}

Table 1 shows the clinical data for the poorly controlled Type 2 diabetic patients $(n=140)$ treated with sulphonylurea or diet alone and for the healthy subjects $(n=85)$ and the concentrations of their perti- nent blood constituents. Approximately $90 \%$ of the diabetic patients were treated with glibenclamide.

\section{Serum collection}

Venous blood was collected after an overnight fast. The blood was placed on ice and then centrifuged at $1500 \mathrm{~g}$ for $15 \mathrm{~min}$ at $4^{\circ} \mathrm{C}$. The sera from four to six subjects were pooled to form one serum batch. Each serum batch was sterilized by filtration $(0.22 \mu \mathrm{m})$ and kept frozen for $1-3$ weeks at $-20^{\circ} \mathrm{C}$. Twenty-eight batches of diabetic sera

Table 1. Clinical data and concentrations of pertinent blood constituents from poorly controlled. Type 2 diabetic patients and non-diabetic subjects in the fasting state

\begin{tabular}{lcc}
\hline & $\begin{array}{l}\text { Diabetic } \\
\text { patients } \\
(n=140)\end{array}$ & $\begin{array}{l}\text { Non-diabetic } \\
\text { subjecs } \\
(n=85)\end{array}$ \\
\hline Age (years) & $62 \pm 9.4$ & $30 \pm 5.6$ \\
Height $(\mathrm{cm})$ & $165 \pm 8.4$ & $172 \pm 7.3$ \\
Weight $(\mathrm{kg})$ & $76.1 \pm 14.8$ & $64 \pm 8.9$ \\
HbA $_{1}(\%)$ & $11.9 \pm 1.4$ & $6.3 \pm 0.6$ \\
Glucose (blood haemolysate) $(\mathrm{mmol} / \mathrm{l})$ & $13.9 \pm 1.6$ & $5.3 \pm 0.4$ \\
Serum cholesterol $(\mathrm{mmol} / 1)$ & $5.9 \pm 1.0$ & $4.8 \pm 0.6$ \\
Serum triglycerides $(\mathrm{mmol} / 1)$ & $2.7 \pm 0.7$ & $1.2 \pm 0.4$ \\
Serum growth hormone $(\mu \mathrm{g} / 1)$ & $2.5 \pm 1.1$ & $3.2 \pm 2.0$ \\
Serum insulin $(\mathrm{mU} / \mathrm{l})$ & $31 \pm 4$ & $10 \pm 2$ \\
Plasma glucagon $(\mathrm{ng} / \mathrm{l})$ & $123 \pm 45$ & $98 \pm 24$ \\
Serum cortisol $(\mathrm{nmol} / \mathrm{l})$ & $368 \pm 60$ & $183 \pm 51$ \\
\hline
\end{tabular}

Results expressed as mean \pm SD 
Table 2. Concentrations of glucose, cholesterol and triglycerides in different batches of pooled sera from fasted diabetic patients and non-diabetic subjects in experiments described in Figures $1-8$ and Table 3

\begin{tabular}{|c|c|c|c|c|c|}
\hline Experiment & Serum & $\begin{array}{l}\text { Number of } \\
\text { serum batches }\end{array}$ & $\begin{array}{l}\text { Glucose } \\
(\mathrm{mmol} / \mathrm{l})\end{array}$ & $\begin{array}{l}\text { Cholesterol } \\
(\mathrm{mmol} / \mathrm{l})\end{array}$ & $\begin{array}{l}\text { Triglycerides } \\
(\mathrm{mmol} / 1)\end{array}$ \\
\hline Figure 1 & Diabetic & 8 & $13.4 \pm 2.8$ & $5.5 \pm 1.3$ & $2.5 \pm 0.4$ \\
\hline Figure 2 & Diabetic & 1 & 12.3 & 3.8 & 2.8 \\
\hline Figure 3 & Diabetic & 10 & $13.9 \pm 1.4$ & $6.2 \pm 0.6$ & $2.7 \pm 0.8$ \\
\hline Figure 4 & Diabetic & 2 & 12.6 & 5.3 & 2.4 \\
\hline Figure 5 & Diabetic & 1 & 14.8 & 6.4 & 3.4 \\
\hline & Non-diabetic & 4 & $5.2 \pm 0.3$ & $5.3 \pm 0.9$ & $1.4 \pm 0.1$ \\
\hline Figure 8 & Diabetic & 6 & $14.5 \pm 0.6$ & $6.1 \pm 0.5$ & $2.7 \pm 0.7$ \\
\hline Table 3 & Diabetic & 3 & $14.3 \pm 0.8$ & $6.4 \pm 0.5$ & $3.5 \pm 0.6$ \\
\hline
\end{tabular}

Results expressed as mean $\pm \mathrm{SD}$

and 17 batches of non-diabetic sera were used. As in previous experiments, single serum samples from poorly controlled Type 2 male and female diabetic patients did not differ in their growth stimulating potency [2], and so the sera from both sexes were pooled. For practical reasons, all pooled sera from diabetic and non-diabetic subjects had a sex ratio of $60 \%$ women: $40 \%$ men. Seven diabetic and 15 non-diabetic subjects contributed twice to different serum batches. Concentrations of glucose, cholesterol and triglycerides in different serum batches used in experiments described in Figures 1-8 and Table 3 are shown in Table 2.

Glycosylated hemoglobin $\left(\mathrm{HbA}_{1}\right)$ was measured chromatographically using microcolumns (normal range: $5.5-8.5 \%$; Panchem, Kleinwallstadt, FRG). Blood glucose, serum cholesterol and triglycerides were determined enzymatically (Glucoquant, Cholesterin CHODPAP, Triglyceride vollenzymatisch, Boehringer Mannheim, FRG). The hormone concentrations were measured using radioimmunoassays: growth hormone (Serono, Freiburg, FRG), insulin (Pharmacia, Freiburg, FRG), glucagon (New England Nuclear, Dreieich, FRG) and cortisol (Biermann, Bad Nauheim, FRG). Glibenclamide levels in the serum dialysate were measured by high pressure liquid chromatography [4] and no glibenclamide was detected (lower detection limit: $50 \mathrm{ng} / \mathrm{ml}$ ).

\section{Serum fractionation}

To remove low molecular weight compounds (mol. wt. $<12,000$ or $<3,500$ ), serum was dialyzed for $48 \mathrm{~h}$ at $4^{\circ} \mathrm{C}$ against 20 volumes of $\mathrm{NaCl}(0.15 \mathrm{~mol} / \mathrm{l})$. The dialysate was discarded and the dialyzed serum fraction used as well as the undialyzed serum of the same batch for the growth experiments.

To examine the growth-stimulating effect of the low molecular weight fractions, serum was dialyzed (mol. wt. $<12,000$ or $<3,500$ ) for $72 \mathrm{~h}$ at $4^{\circ} \mathrm{C}$ against 10 volumes of distilled water. In addition, diabetic serum dialysate (mol. wt. $<3,500$ ) was filtered (mol. wt. cut-off 500; Table 3). The dialysate or ultrafiltrate was concentrated to dryness by a rotatory evaporator (Janke \& Kunkel, Stauffen, FRG) at $37^{\circ} \mathrm{C}$ and reconstituted with distilled water to the original serum volume. This low molecular weight serum fraction was always used in combination with dialyzed serum of the same batch, either in a concentration equivalent to the amount contained in the dialyzed serum fraction before dialysis once or to an amount $2,4,6,10$ and 20 times higher than the original concentration of this serum fraction.

To keep the osmolarity of the incubation medium constant, 10 times concentrated Dulbecco's modification of Eagle's medium without sodium chloride was diluted to the original concentration with distilled water that contained the low molecular weight serum fraction. Thereafter, the osmolarity was adjusted to 280 mosmol by addition of appropiate amounts of sodium chloride. This medium was combined with dialyzed serum at the given concentrations.

\section{Cultured cells}

Arterial smooth muscle cells were derived from the abdominal aorta of a non-diabetic 50-year-old patient [3]. The cells were used between the third and sixth passage number and, during the experiments, retained the characteristic features of arterial smooth muscle cells in culture.

Fibroblast cultures were derived from adult human skin biopsies of the deltoid region by established methods [3]. Each experiment was performed on one cell line between the fifth and tenth passage number. Within these passage numbers, no significant changes of the growth rate were observed. For the same set of experiments, cell cultures with approximatly the same number of passages have been compared. Cells $\left(3-4 \times 10^{4}\right)$ were seeded per $35 \mathrm{~mm}$ culture plate and grown for 6-7 days until confluency in $2 \mathrm{ml}$ Dulbecco's modification of Eagle's medium supplemented with 1, 5 or $10 \%$ (vol/vol) of the respective serum or dialyzed serum at $37^{\circ} \mathrm{C}$ in a humidified atmosphere of $95 \%$ air and $5 \% \mathrm{CO}_{2}$, with two medium changes. Cells were counted from quadruplicate plates after short trypsinization, using a Coulter Counter (Model ZBI, Krefeld, FRG).

\section{Growth assays}

To compare the relative growth potency of the low molecular weight diabetic serum fraction with the growth effect of various hormones, whose serum concentrations can be raised in diabetes, the cells were grown in Dulbecco's modification of Eagle's medium $+10 \%$ dialyzed diabetic serum (mol. wt. $>12,000$ ) + the following final medium concentrations in parallel plates: the low molecular weight diabetic serum fraction (mol. wt. $<3,500$ ) equivalent to the amount in $10 \%$ diabetic serum; growth hormone ( 3 and $30 \mu \mathrm{g} / 1$ ); insulin $(3,30$ and $300 \mathrm{mU} / \mathrm{l})$; glucagon $(0.5,5$ and $50 \mu \mathrm{g} / \mathrm{l})$ and cortisol $(8,80$ and $800 \mathrm{nmol} / \mathrm{l}$ ). To allow for direct comparison of different experiments, the results were expressed as percentage cell growth (mean $\pm \mathrm{SD}$ ), setting as $100 \%$, the cell number/plate at day 6 in Dulbecco's modification of Eagle's medium $+10 \%$ dialyzed diabetic serum.

To study the effect of proteases on the low molecular weight growth factor, the diabetic serum dialysate (mol. wt. $<3,500$ ) was incubated with pronase $\mathrm{E}$ or B. subtilis protease $\left(200 \mu \mathrm{g} / \mathrm{ml} ; 4 \mathrm{~h}, 25^{\circ} \mathrm{C}\right.$, $\mathrm{pH} 7.0$ or 7.5 ). Thereafter, the serum growth fraction was separated from the proteases by dialysis (mol. wt. cut-off 12,000 ) for $2 \times 12 \mathrm{~h}$ versus 10 volumes of distilled water at $4{ }^{\circ} \mathrm{C}$. This dialysate was concentrated to dryness and treated as described previously. For control purposes, parallel samples of diabetic serum dialysate were handled with heat-inactivated pronase. Without further storage, the growth effect of these two low molecular weight serum fractions was compared to the same, but untreated, diabetic serum fraction in parallel plates. To allow for direct comparison of six diabetic serum batches, the results were expressed as percentage cell growth (mean $\pm \mathrm{SD}$ ), setting $100 \%$, 
the cell number/plate at day 5 in Dulbecco's modification of Eagle's medium $+10 \%$ dialyzed diabetic serum + the untreated diabetic serum dialysate.

\section{Materials}

Dulbecco's modification of Eagle's medium with a glucose concentration of $5.5 \mathrm{mmol} / \mathrm{l}$ (Seromed, Munich, FRG), penicillin/ streptomycin solution (Seromed), trypsin-EDTA solution (Gibco, Paisley, UK), pronase E from Streptomyceus griseus (EC 3.4.24.4, Serva Feinbiochemica, Heidelberg, FRG), protease (bacterial, Subtilisin carlsberg, EC 3.4.4.16; Calbiochem, Giessen, FRG); human insulin and pork glucagon (Novo Industrie, Mainz, FRG), hydrocortisone (Sigma, St. Louis, Missouri, USA), cell culture plates $(20,35$ or $60 \mathrm{~mm}$ diameter; Beckton \& Dickinson, Heidelberg, FRG); seamless cellulose tubing $18 / 32$ with an exclusion limit of $8,000-12,000$ daltons (Serva, Heidelberg, FRG): this type retained cytochrome C (mol. wt. 12,400) completely, whereas insulin (mol. wt. 6,000) was removed. Spectrapor 6 membrane with an exclusion limit of 3,500 daltons (Berghof, Tübingen, FRG): this type retained insulin completely, whereas glucagon (mol. wt. 3,500) was removed. UMO5 filter system with a nominal molecular weight cut-off 500 daltons (Amicon, Witten, FRG).

Statistical analysis. Two-tailed Student's t-test was used.

\section{Results}

Removal of the low molecular weight growth fraction (mol. wt. $<12,000$ ) from eight sera of poorly controlled Type 2 diabetic subjects reduced the growth-stimulating effect of the remaining serum growth factors on human fibroblasts by an average of $36.5 \%(2 p<0.005)$ compared with diabetic serum (Fig. 1).

Removal of this growth stimulating fraction from eight sera of non-diabetic subjects also reduced the growth-stimulating effect on fibroblasts of the remaining serum growth factors, but only by an average of $8 \%$ $(2 p<0.01)$ compared with non-diabetic serum (Fig. 1).

This difference in effect on cell growth between diabetic and non-diabetic sera was due to differences in low molecular weight growth factor(s), as the effect of dialyzed diabetic sera (mol. wt. $>12,000$ ) did not differ from that of dialyzed non-diabetic sera (Fig. 1).

The low molecular weight diabetic serum growth fraction is also dialyzable through a membrane with a molecular weight cut-off of 3,500 (Figs. 2 and 3) and can be completely ultrafiltrated (nominal mol. wt. cut-off 500 ; Table 3). The recombination of dialyzed diabetic sera with their dialysates (mol. wt. $<3,500$ ) or ultrafil-

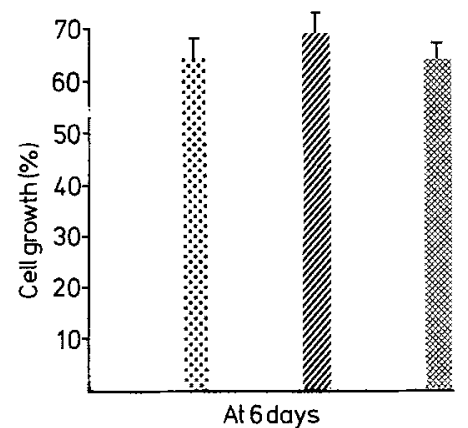

Fig.1. Effect of eight serum batches from poorly controlled Type 2 diabetic patients, their dialyzed serum fraction (mol. wt. $>12,000$ ) ( $\mathrm{B}$ ), eight serum batches from non-diabetic subjects ( $\mathbb{Z}$ ) and their dialyzed serum fraction (mol. wt. $>12,000$ ) (䛜) on human fibroblast growth. The cell number/plate on day 6 , achieved with diabetic serum, was taken as $100 \%$ (mean $\pm \mathrm{SD}$ )

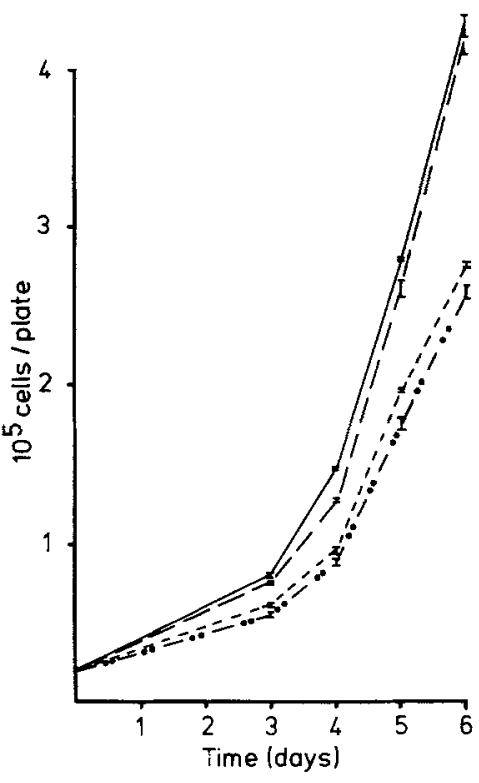

Fig. 2. Effect of one batch of diabetic sera from poorly controlled Type 2 diabetic patients (-), of dialyzed diabetic serum (mol. wt. $>12,000)(---)$, of dialyzed diabetic serum (mol. wt. $>3,500)(-\cdots-)$ and equivalent amounts of its dialysate (mol. wt. $<3,500$ ) recombined with the dialyzed diabetic serum (mol. wt. $>12,000)(--)$ on fibroblast growth

Table 3. Effect of different diabetic serum fractions from three serum batches on human fibroblast growth after 7 days of incubation in Dulbecco's modification of Eagle's medium $+10 \%$ of the respective serum fraction

\begin{tabular}{|c|c|c|c|c|c|c|}
\hline $\begin{array}{l}\text { Serum batch } \\
\text { (number) }\end{array}$ & \multicolumn{2}{|c|}{ Dialyzed serum ${ }^{a}$} & \multicolumn{2}{|c|}{ Dialyzed serum $^{a}+$ its dialysate ${ }^{b}$} & \multicolumn{2}{|c|}{ Dialyzed serum $^{\mathrm{a}}+$ its $_{\text {ultrafiltrate }}^{c}$} \\
\hline 1 & 293,240 & 54 & 542,120 & 100 & 540,280 & 100 \\
\hline 3 & 127,440 & 59 & 215,820 & 100 & 212,720 & 99 \\
\hline
\end{tabular}

${ }^{a}$ Mol. wt. $>3,500 ;{ }^{b}$ mol. wt. $<3,500 ;{ }^{c}$ UMO5 filtered fraction (nominal mol. wt. cut-off 500 ) of the serum dialysate (b); the growth effect achieved with (a) + (b) was taken as $100 \%$. Cell counts represent the mean from quadruplicate plates (SD $<5 \%$ ) 


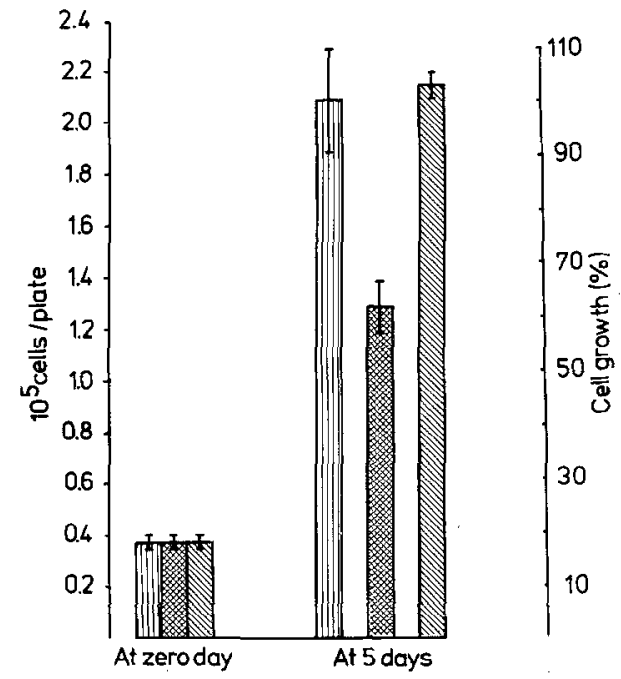

Fig. 3. Effect of 10 sera from poorly controlled Type 2 diabetic subjects ( [ [I] ), their dialyzed serum fractions (mol. wt. $>3,500$ ) (夙) and the recombination of their dialyzed diabetic serum fractions and equivalent amounts of their dialysates (mol. wt. $<3,500$ ) ( on fibroblast growth after 5 days of incubation (mean $\pm \mathrm{SD}$ )

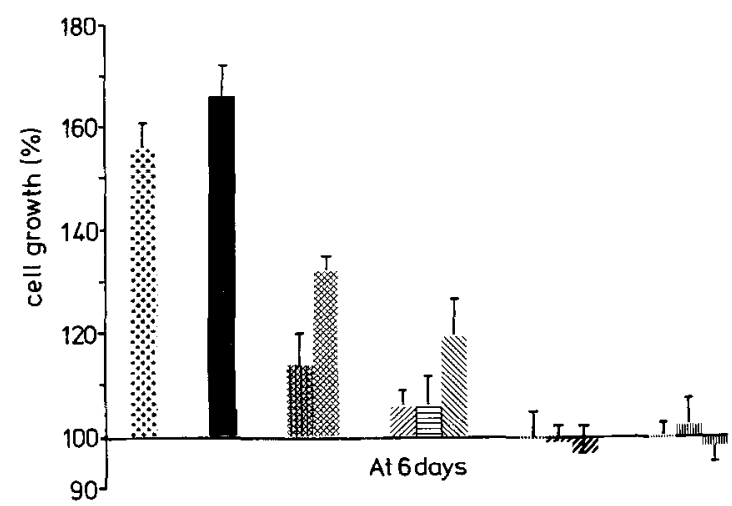

Fig.4. Effect of two diabetic sera from poorly controlled Type 2 diabetic patients ( $\beta$ ) and their dialyzed sera (mol. wt. $>12,000$ ) in combination with equivalent amounts of their dialysates (mol. wt. $<3,500)(\square)$, human growth hormone (final medium concentration: 3 or $30 \mu \mathrm{g} / \mathrm{l}$ ) (閣, 网), insulin $(3,30$ or $300 \mathrm{mU} / \mathrm{l}$ ) (四, 貣, glucagon $(0.5,5$ or $50 \mu \mathrm{g} / \mathrm{l})(\mathbb{Z})$ or cortisol $(8,80$ or $800 \mathrm{nmol} / \mathrm{l})(\mathbb{U})$ on fibroblast growth. The cell number/plate on day 6 , achieved with dialyzed diabetic serum, was taken as $100 \%$ (mean $\pm \mathrm{SD}$ )

trates, both stimulated fibroblast growth to the same degree $(23-46 \%)$ and fully restored the growth effect of the original undialyzed diabetic sera (Figs. 2-4, Table 3). The growth effect on fibroblasts of the dialyzed diabetic serum (mol. wt. $>3,500$ ) did not differ from that of dialyzed diabetic serum (mol. wt. $>12,000$ ) as shown in a representative experiment in Figure 2.

The growth potency of the low molecular weight growth fraction (mol. wt. $>3,500$ ) contained in $10 \%$ diabetic serum was 2-10 times higher than that of human growth hormone or insulin, added in amounts equivalent to $10 \%$ serum or physiological concentrations, whereas glucagon and cortisol did not show any growth activity above the basal level in human fibroblasts (Fig. 4).

The low molecular weight growth factor of diabetic sera (mol. wt. $<3,500)$ stimulated fibroblast growth

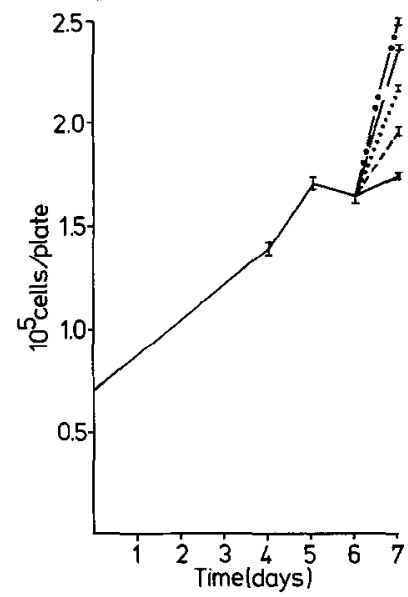

Fig.5. Effect of 1-10 times concentration of the low molecular weight diabetic serum growth fraction (mol. wt. $<3,500$ ) from poorly controlled Type 2 diabetic patients on fibroblast growth. Cells were grown until day 4 in Dulbecco's modification of Eagle's medium + $10 \%$ diabetic serum. On day 4 , the incubation medium was changed to Dulbecco's modification of Eagle's medium $+1 \%$ diabetic serum. After growth arrest, the incubation medium was changed again on day 6 to Dulbecco's modification of Eagle's medium $+1 \%$ dialyzed diabetic serum (mol. wt. $>3,500)+0(-), 2(---), 4(\cdots \cdots \cdots), 6$ $(--)$ and 10 times $(-\cdots-)$ that of the original concentration in $1 \%$ diabetic serum. The same diabetic serum was used throughout the experiment

above the basal level achieved with dialyzed diabetic sera, linearly up to 20 times that of the original diabetic serum concentrations as shown in two representative experiments (Figs. 5 and 6). This additional growthstimulating effect was already apparent $24 \mathrm{~h}$ after addition of these growth factor(s) to growth arrested cells (Fig. 5) and remained effective during the whole growth period to confluency (Fig. 6).

Under the conditions of the experiment shown in Figure 6, the low molecular weight growth factor (mol. wt. $<3,500$ ) from eight diabetic sera stimulated fibroblast growth by $243 \pm 56 \%$ (mean \pm SD) and from five non-diabetic sera by $146 \pm 27 \%(2 p<0.01$, diabetic versus non-diabetic sera) when added in 10 times concentration.

Under the same experimental conditions, the low molecular weight growth factor (mol. wt. $<3,500$ ) from three diabetic sera also stimulated human arterial smooth muscle cell growth by an average of $174 \%$ and from four non-diabetic sera by an average of $137 \%$ $(2 p<0.001$, diabetic versus non-diabetic sera), when added in 10 times concentration (Fig. 7). Similar to the results obtained with fibroblasts, the different effect on cell growth of diabetic and non-diabetic sera was due to differences in the low molecular weight growth factor (mol. wt. $<3,500$ ), as dialyzed diabetic and non-diabetic sera (mol. wt. $>12,000$ ) stimulated arterial smooth muscle cell growth to the same degree (Fig.7).

The low molecular weight diabetic serum growth fraction (mol. wt. $<3,500$ ) remained active after storage at $-20^{\circ} \mathrm{C}$ for at least 8 weeks, after $60 \mathrm{~min}$ at $\mathrm{pH} 2-11$ and after treatment with $20 \mathrm{ml}$ chloroform/methanol $(2: 1 ; \mathrm{vol} / \mathrm{vol})$ of $1 \mathrm{ml}$ of the serum fraction. In contrast, 


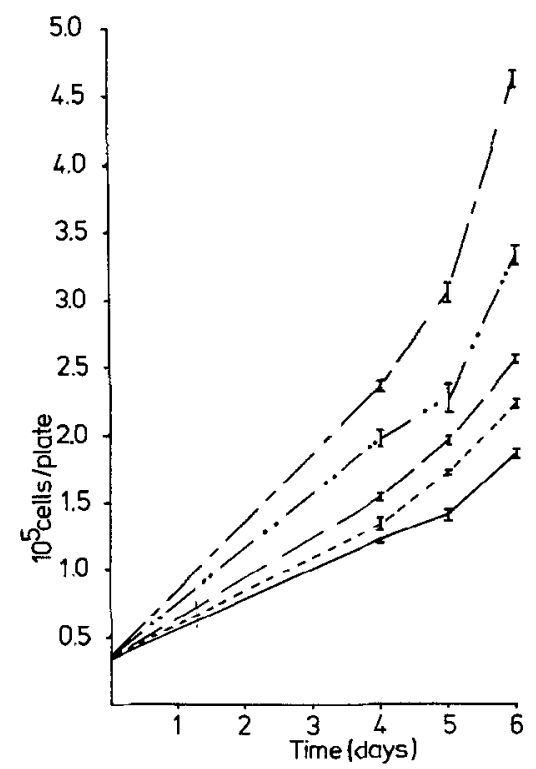

Fig. 6. Effect of 2-20 times concentration of the low molecular weight diabetic serum growth factor (mol. wt. $<3,500$ ) from poorly controlled Type 2 diabetic patients on fibroblast growth. Cells were grown for 6 days in Dulbecco's modification of Eagle's medium + $5 \%$ dialyzed diabetic serum (mol. wt. $>12,000)+0(-), 2(---), 6$ $(--), 10(-\ldots)$ and $20(--)$ times that of the original concentration in $5 \%$ diabetic serum. The same diabetic serum was used throughout the experiment

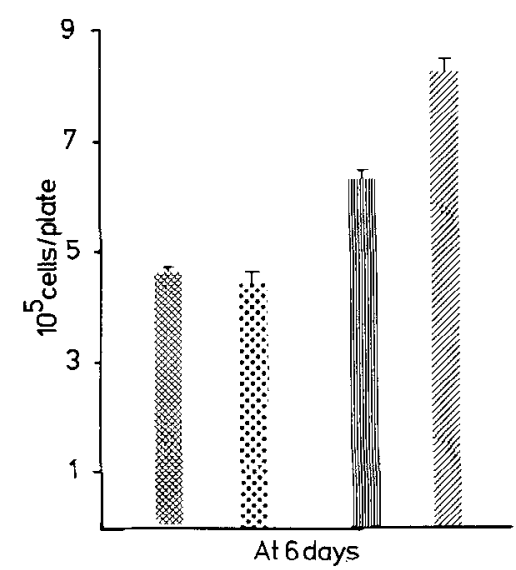

Fig.7. Different growth stimulation of human arterial smooth muscle cells after 6 days of incubation in Dulbecco's modification of Eagle's medium $+5 \%$ dialyzed non-diabetic $(n=4)$ (网) or diabetic sera $(n=3)(13)$ (mol. wt. $>12,000)$ and their recombination with the serum dialysate fraction (mol. wt. $<3,500$ ) of the same batch, equivalent to 10 times that of the original concentration in $5 \%$ non-diabetic ( or diabetic sera (

30 min at $95^{\circ} \mathrm{C}$ reduced the growth effect of this diabetic serum fraction to the control levels.

Proteases also completely abolished $(2 p<0.001)$ the growth effect of the low molecular weight growth fraction (mol. wt. $<3,500$ ) from six diabetic sera, as shown in Figure 8. Analogous effects could be demonstrated for Bacterium subtilis protease.

\section{Discussion}

Abnormal cell growth is recognised as an intrinsic factor in the angiopathic process in both diabetic and non-

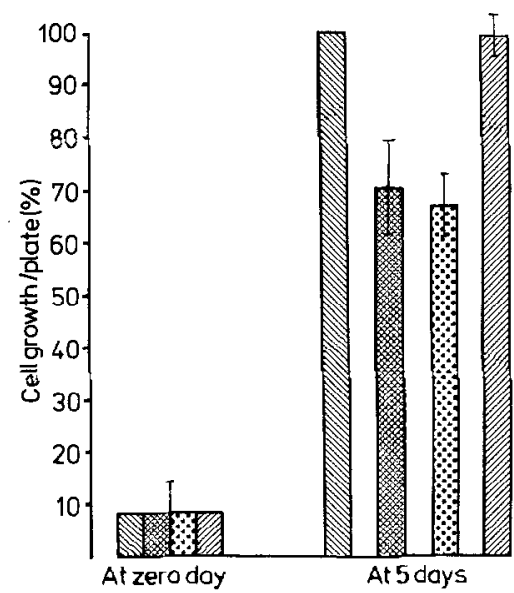

Fig.8. Effect of pronase pre-incubation of the low molecular weight growth fraction (mol. wt. $<3,500$ ) from six diabetic sera on fibroblast growth. Cells were grown in Dulbecco's modification of Eagle's medium $+10 \%$ of dialyzed diabetic serum (mol. wt. $>3,500)($ ), the equivalent combination of $10 \%$ dialyzed diabetic serum + its untreated dialysate (㭡) or its dialysate pretreated with active pronase ( or with heat-inactivated pronase ( The cell number/plate on day 5 , achieved with the combination of dialyzed diabetic senum + its untreated dialysate was taken as $100 \%$ (mean \pm SD)

diabetic atherosclerosis [5-8]. A major role has been attributed to the abnormal metabolic environment in both Type 1 (insulin-dependent) and Type 2 diabetes [8-10], although the nature of any factor(s) with additional growth-stimulating effect in diabetic sera has remained uncertain. Several possible candidates, whose blood levels can increase under various conditions in diabetes, have been considered. These include growth hormone [11-12], insulin [8, 13-15], cortisol [16], lipoproteins [17-19] and glucose [20-22].

In this study, the serum growth hormone levels were normal. Serum insulin levels increased up to $38 \mathrm{mU} / 1$, but only at $300 \mathrm{mU} / 1$, was a growth stimulation effect seen (Fig. 4). This concentration is far in excess of the final insulin concentration of $2-4 \mathrm{mU} / 1$, present in the incubation medium with $10 \%$ dialyzed diabetic serum. In addition, growth hormone, insulin, and many other well-established growth peptides for vascular cells [6, $16,23]$, e.g. macrophage/monocyte-derived growth factor, endothelial cell growth factor, endothelial cell-derived growth factor, platelet-derived growth factor, fibroblast growth factor, epidermal growth factor, insulinlike growth factors I and II or transferrin and lipoproteins, even if their concentrations are increased, are unlikely to be responsible, as the additional growth-stimulating effect is mainly related to one or more serum factor(s) of very low molecular weight.

This does not imply that serum factors with a molecular weight $>12,000$ could not contribute to the increased cellular growth in diabetic subjects, although their importance seems limited. This is in line with the fact that dialyzed serum is essential for growth initiation and continuous stimulation and that dialyzed diabetic and non-diabetic serum affect cellular growth similarly [1].

Other low molecular weight serum compounds, such as glucagon and cortisol whose blood concentra- 
tions are slightly increased in Type 2 diabetes, did not stimulate cell growth over a wide concentration range and, therefore, cannot be regarded as growth factors. Glucose has already been shown to decrease the growth of fibroblasts [1] and endothelial cells [22] at higher concentrations.

Specific growth effects of the sulphonylureas in diabetic serum have been excluded by two facts: (1) single serum batches from poorly controlled diabetic patients treated with diet alone showed a similar increased growth stimulation of fibroblasts; and (2) diabetic serum dialysates (mol. wt. $<3,500$ ) did not contain measurable amounts of glibenclamide.

A specific effect of sex on the growth stimulation of the diabetic serum fraction with very low molecular weight has not been observed previously [2]. This fact agrees well with the clinical observation that large vessel disease in diabetic patients is not dependent on sex, in contrast to non-diabetic subjects.

The growth effect of the diabetic serum fraction with very low molecular weight $(<3,500)$ is not specific for diabetes, as the same serum fraction exists in nondiabetic subjects and may, to a lesser degree, stimulate fibroblast growth. This agrees with the fact that the stimulation of growth induced by this diabetic serum fraction works equally well in combination with dialyzed diabetic and non-diabetic sera [1].

These results demonstrate the existence in man of a very low molecular weight serum fraction whose growth effect on cultured human arterial smooth muscle cells and fibroblasts increases in Type 2 diabetic subjects with worsening of metabolic control. This increase is regulated by metabolic factors, as it is reduced by good metabolic control [2].

As the growth potency of the very low molecular weight diabetic serum fraction on cultured fibroblasts exceeds 2-10 times that of insulin and growth hormone, similar effects could also be expected in the vascular wall as this growth fraction could easily penetrate the vascular wall because of its very low molecular weight.

The very low molecular weight serum growth factor(s) has a peptide nature and is thus similar to many growth peptides for vascular cells $[6,16]$. Its isolation and characterization is required for the further understanding of the nature of possible vascular risk factors in Type 2 diabetes.

Acknowledgements. This work has been supported, in part, by the Deutsche Forschungsgemeinschaft SFB 113 (F4), the Ministerium für Forschung und Wissenschaft in NRW and the Paul-Kuth-Stiftung. The glibenclamide measurements were kindly performed by Professor H. Reinauer and Dr. F. Susanto, Department of Biochemistry, Diabetes Research Institute, Düsseldorf, FRG.

\section{References}

1. Koschinsky T, Bünting CE, Schwippert B, Gries FA (1980) Increased growth stimulation of fibroblasts from diabetics by diabetic serum factors of low molecular weight. Atherosclerosis 37: 311-317

2. Koschinsky T, Bünting CE, Schwippert B, Gries FA (1981) Regulation of diabetic serum growth factors for human vascular cells by the metabolic control of diabetes mellitus. Atherosclerosis 39: $313-319$
3. Koschinsky T, Bünting CE, Schwippert B, Gries FA (1979) Increased growth of human fibroblasts and arterial smooth muscle cells from diabetic patients related to diabetic serum factors and cell origin. Atherosclerosis 33: 245-252

4. Lindner G, Herbertz L, Reinauer H (1980) Bestimmung von Glibenclamid mit Radioimmunoassay und Hochdruckflüssigkeitschromatographie im Serum von Diabetikern. Lab Med 4: 34-38

5. Ross R, Glomset JA (1973) Atherosclerosis and the arterial smooth muscle cell. Science 180: 1332-1339

6. Schwarz SM, Gajdusek CM (1982) Growth factors and the vessel wall. In: Spaet TH (ed) Progress in hemostasis and thrombosis 6. Grune \& Stratton, New York, pp 85-112

7. Hauss WH, Mey J, Schulte H (1979) Effect of risk factors and antirheumatic drugs on the proliferation of aortic wall cells. Atherosclerosis 34: 119-143

8. Stout RW (1979) Diabetes and atherosclerosis - the role of insulin. Diabetologia 16: 141-150

9. Kannel WB, McGee DL (1979) Diabetes and glucose tolerance as risk factors for cardiovascular disease: the Framingham Study. Diabetes Care 2: 120-126

10. Keen H, Rose G, Pyke DA (1965) Blood-sugar and arterial disease. Lancet 2: 505-511

11. Ledet $T$ (1976) Growth hormone stimulating the growth of arterial medial cells in vitro - absence of effect of insulin. Diabetes 25: 1011-1017

12. Ledet T (1977) Growth hormone antiserum suppresses the growth effect of diabetic serum. Diabetes 26: 798-803

13. Stout RW, Biermann EL, Ross R (1975) Effect of insulin on the proliferation of cultured primate arterial smooth muscle cells. Circulation Research 36:319-327

14. Hollenberg MD, Cuatrecasas P (1975) Insulin: interaction with membrane receptors and relationship to cyclic purine nucleotides and cell growth. Fed Proc 34: 1556-1563

15. King GL, Buzney SM, Kahn CR, Hetu N, Buchwald S, MacDonald SG, Rand LI (1983) Differential responsiveness to insulin of endothelial and support cells from micro- and macrovessels. J Clin Invest 71: 974-979

16. Hayashi I, Larner J, Sato G (1978) Hormonal growth control of cells in culture. In Vitro 14: $23-30$

17. Ledet T, Fischer-Dzoga K, Wissler RW (1976) Growth of rabbit aortic smooth-muscle cells cultured in media containing diabetic and hyperlipemic serum. Diabetes 25: 207-215

18. Fischer-Dzoga K, Wissler RW (1976) Stimulation of proliferation in stationary primary cultures of monkey aortic smooth muscle cells. Effect of varying concentrations of hyperlipemic serum and low density lipoproteins of varying dietary fat origins. Atherosclerosis 24: $515-525$

19. Fless GM, Kirchhausen T, Fischer-Dzoga K, Wissler RW, Scanu AM (1982) Serum low density lipoproteins with mitogenic effect on cultured aortic smooth muscle cells. Atherosclerosis 41: 171-183

20. Turner JL, Biermann EL (1978) Effects of glucose and sorbitol on proliferation of cultured human skin fibroblasts and arterial smooth-muscle cells. Diabetes 27: 583-588

21. Stout RW (1981) Blood glucose and atherosclerosis. Arteriosclerosis $1: 227-234$

22. Stout RW (1982) Glucose inhibits replication of cultured human endothelial cells. Diabetologia 23: 436-439

23. Rinderknecht F, Humbel RE (1976) Polypeptides with nonsuppressible insulin-like and cell-growth promoting activities in human serum: isolation, chemical characterization, and some biological properties of forms I and II. Proc Natl Acad Sci USA 73: $2365-2369$

Received: 8 March 1984

and in revised form: 12 February 1985

Dr. Theodor Koschinsky

Diabetes Research Institute

Auf'm Hennekamp 65

D-4000 Düsseldorf 1

FRG 